\title{
Studi Literatur: Pemanfaatan Powerpoint Interaktif sebagai Media Pembelajaran Biologi di SMA
}

\author{
Titin $^{1 *}$, Iin Kurnia ${ }^{1}$ \\ ${ }^{1}$ Fakultas Keguruan dan Ilmu Pendidikan, Jurusan PMIPA, Program Studi Pendidikan Biologi, \\ Universitas Tanjungpura \\ *email: titin@fkip.untan.ac.id
}

\begin{abstract}
Article History
Received:

20/08/2021

Revised:

14/09/2021

Accepted:

25/09/2021

Kata kunci:

Pendidikan

Powerpoint

Interaktif

Sekolah

ABSTRAK

Powerpoint interaktif adalah slide interaktif yang berisi materi pembelajaran sehingga dapat dimanfaatkan penggunanya untuk mendapatkan informasi dan pengetahuan dari media tersebut. Guru dalam proses pembelajaran biologi di sekolah menengah atas dituntut dapat memanfaatkan media. Saat ini, pemanfaatan powerpoint interaktif untuk pembelajaran juga banyak ditemukan. Maka dari itu peneliti akan mengulas powerpoint interaktif yang dapat dimanfaatkan sebagai media pembelajaran biologi khususnya pada tingkat sekolah menengah atas serta kelebihan dan kekurangan terhadap pembelajaran. Adapun metode studi literatur ini yaitu tinjauan sistematis (systematic literature review). Berdasarkan hasil penelitian studi literatur, bahwasanya pemanfaatan powerpoint interaktif sebagai media pembelajaran biologi di SMA memudahkan peserta didik dalam memahami materi pelajaran, penggunaannya praktis, menyampaikan informasi dengan jelas karena penyajian yang lebih menarik sehingga menumbuhkan motivasi dan meningkatkan hasil belajar peserta didik.
\end{abstract}

Menengah Atas$$
\text { ABSTRACT }
$$

Interactive PowerPoint is an interactive slide that contains learning material so that users can use it to get information and knowledge from the media. Teachers in the process of learning biology in high schools are required to be able to utilize the media. Currently, the use of interactive powerpoint for learning is also widely found. Therefore, researchers will review interactive powerpoints that can be used as a medium for learning biology, especially at the high school level and the advantages and disadvantages of learning. The method of this literature study is a systematic review (systematic literature review). Based on the results of literature study research, that the use of interactive powerpoint as a medium for learning biology in high school makes it easier for students to understand the subject matter, its use is practical, conveys information clearly because the presentation is more attractive so as to foster motivation and improve student learning outcomes.
\end{abstract}

Copyright (C) 2022 LPPM Universitas Indraprasta PGRI. All Right Reserved

\section{PENDAHULUAN}

Pendidikan adalah cara untuk mempersiapkan generasi muda dalam menyambut dan menghadapi adanya perkembangan pada saat ini dan masa yang akan datang. Pendidikan harus diberikan sebaik mungkin sehingga dapat menghasilkan pendidikan yang bermutu dan meningkatnya mutu dari sumber daya manusia (SDM). Perkembangan teknologi berpengaruh pada pendidikan. Proses dalam pembelajaran selalu terkait dengan media pembelajaran, metode mengajar, dan hasil belajar. Dalam pembelajaran biologi, beberapa materi tertentu memerlukan adanya bantuan media pembelajaran untuk dapat membantu peserta didik dalam memahami materi pelajaran. Media dapat digunakan sebagai sarana dalam menyampaikan materi dari guru kepada peserta didik (Pramuaji, 2017). Metode belajar mengatur tentang bahan ajar dan strategi dalam penyampaiannya. Selanjutnya hasil belajar diukur dengan melihat keefektifan untuk mengetahui 
kemampuan dan minat peserta didik terhadap mata pelajaran biologi.

Pembelajaran seharusnya dilakukan dengan cara yang dapat menyenangkan peserta didik. Akan tetapi, kenyataan yang terjadi pada proses pembelajaran khususnya pembelajaran biologi peserta didik masih memiliki anggapan yang kurang baik. Berdasarkan hasil pengamatan di sekolah, pada proses kegiatan belajar mengajar biologi guru menyampaikan materi hanya secara teoritis saja sehingga cenderung membuat peserta didik menghafal, tidak ada penerapan, peserta didik kurang aktif, stigma pembelajaran biologi sulit, dan banyak istilah latin yang susah untuk dimengerti. Terkait hal tersebut, Jayawardana (2017) mengungkapkan bahwa peserta didik menganggap pada pembelajaran biologi merupakan pelajaran menghafal, sehingga proses pembelajaran yang terjadi adalah peserta didik hanya mendengarkan dan mencatat apa yang telah didapatkan dari guru. Pembelajaran di kelas lebih diarahkan pada kemampuan peserta didik untuk memahami materi pelajaran. Sedangkan teori yang dipelajari peserta didik kurang adanya penerapan dalam kehidupan sehari-hari. Hal ini menyebabkan peserta didik kurang mengerti lebih dalam berkaitan dengan materi biologi yang diajarkan. Dalam kegiatan belajar mengajar biologi, adanya media diharapkan bisa menumbuhkan dan mengembangkan kemampuan serta kreativitas yang dimiliki peserta didik. Sehingga peserta didik memiliki kognitif, afektif, dan psikomotorik tidak hanya secara teoritis, tetapi dapat menerapkannya di masa yang akan datang sesuai dengan kemajuan zaman.

Media pembelajaran adalah bagian penting dalam proses pembelajaran. Media pembelajaran adalah sumber belajar yang bisa membantu guru dalam meningkatkan pengetahuan peserta didik, dengan berbagai jenis media pembelajaran yang digunakan oleh guru maka dapat menjadi bahan dalam memberikan ilmu pengetahuan kepada peserta didik (Nurrita, 2018). Media pembelajaran terdiri dari dua kata, yaitu media dan pembelajaran. Menurut Maskur et al. (2017), media merupakan alat bantu untuk peserta didik dan guru pada proses pembelajaran. Media pembelajaran adalah alat untuk menyampaikan informasi atau pesan, ransangan pikiran, perasaan, dan perhatian, serta kemauan peserta didik sehingga dapat mendorong terjadinya proses belajar dapat dikendalikan (Alwi, 2017).

Media pembelajaran yang menarik bagi peserta didik bisa menjadi rangsangan dalam proses pembelajaran. Pengelolaan alat bantu pembelajaran sangat dibutuhkan dalam lembaga pendidikan formal seperti SMA. Media pembelajaran bisa dijadikan sebagai media bantu pada kegiatan belajar mengajar biologi (Alfan \& Sulistiyo, 2015). Sebagai guru harus dapat menentukan media yang cocok untuk digunakan dalam pembelajaran biologi sehingga tercapai tujuan pengajaran yang telah ditetapkan oleh sekolah.

Menurut (Wahyuningtyas, 2017) media pembelajaran cukup beragam mulai dari audio, visual, audiovisual, dan multimedia. Media pembelajaran yang dipaparkan yaitu multimedia. Multimedia merupakan sistem pemindah data dari segala bentuk informasi berupa teks, gambar, video audio, angka atau kata-kata yang mana komputer akan mengolah informasi tersebut dalam bentuk data dan digital dengan melibatkan pengguna sebagai pengontrolnya. Multimedia terbagi menjadi tiga jenis yaitu multimedia interaktif, multimedia hiperaktif, dan multimedia linear. Salah satu program berbasis multimedia interaktif yakni media powerpoint interaktif.

Powerpoint interaktif adalah sebuah media yang dapat memudahkan penggunanya untuk mendapatkan informasi dan pengetahuan dari media tersebut. Media powerpoint interaktif merupakan slide interaktif yang berisi materi pembelajaran sehingga bisa dimanfaatkan sebagai media dalam pembelajaran. Powerpoint suatu program berbasis multimedia yang dilengkapi dengan fitur-fitur menarik yang dirancang secara khusus sebagai alat presentasi yang memiliki kemampuan pengolahan teks, warna, gambar, dan animasi yang bisa diolah sendiri sesuai dengan kreativitas dari penggunanya (Nurhidayati et al., 2019)

Media pembelajaran bisa menumbuhkan minat peserta didik untuk mempelajari hal baru dalam materi biologi sehingga peserta didik lebih mudah memahami materi. Pemanfaatan media powerpoint interaktif sudah menjadi kebutuhan pada kegiatan pembelajaran biologi dengan latar belakang modern saat ini. Peserta didik akan dapat terbantu dengan adanya powerpoint interaktif ini seperti mudah memahami, praktis, mudah digunakan, tempo, dan cara penyajian dapat disesuaikan serta lain-lain. Kelebihan dari media ini dapat digunakan dalam aplikasi android. Peserta didik sebagai pengguna tidak memerlukan internet dan dapat menyesuaikan halaman yang diinginkan dengan menggunakan tombol navigasi yang tersedia, dengan begitu peserta didik bisa 
paham terhadap materi pembelajaran sesuai dengan kecepatannya masing-masing. Selain itu, powerpoint interaktif ini dapat digunakan secara berkelompok atau mandiri tanpa megharuskan adanya kehadiran guru. Kekurangan dari media ini adalah bila akan digunakan di kelas maka sekolah harus memfasilitasi listrik maupun proyektor dalam proses pembelajaran (Utami, 2021).

Menurut Damayanti \& Qohar (2019) dalam penelitiannya mengatakan bahwa dengan menggunakan powerpoint interaktif dalam pelaksanaan pembelajaran biologi direspons dengan sangat tinggi sehingga dapat meningkatkan pemahaman peserta didik. Pendidik harus mengintegrasikan powerpoint interaktif atau media lain untuk digunakan sebagai platform pembelajaran. Suasana kelas akan lebih menarik dan peserta didik cenderung lebih aktif dalam berbagi pendapat.

Berdasarkan permasalahan yang telah dijelaskan di atas, peneliti akan melakukan penelitian dengan judul "Studi Literatur Pemanfaatan Powerpoint Interaktif sebagai Media Pembelajaran Biologi di SMA" dimana akan mengulas powerpoint Interaktif yang dapat dimanfaatkan sebagai media pembelajaran biologi khususnya untuk sekolah menengah atas.

\section{METODE PENELITIAN}

Objek yang digunakan adalah peserta didik, alat yang digunakan handphone, dan metode yakni studi literatur berupa tinjauan sistematis (systematic literature review). Bertujuan mengidentifikasi, mengkaji, serta mengevaluasi penelitian tertentu yang sesuai sehingga akan menghasilkan jawaban dari penelitian yang dilakukan (Purworaharjo \& Firmansyah, 2018).

\section{HASIL DAN PEMBAHASAN}

Media merupakan bagian dari komponen sistem pembelajaran. Dengan adanya kemajuan teknologi informasi maka guru dalam memberikan materi pelajaran khususnya pelajaran biologi harus mengikuti kemajuan. Guru harus dapat mengaplikasikan media pembelajaran dengan lebih menarik, menyenangkan, dan sesuai dengan kebutuhan belajar peserta didik. Sehingga peserta didik dapat dengan mudah menerima pelajaran yang diberikan oleh guru.

Menurut Tafonao (2018) peran media pembelajaran sebagai media bantu pada kegiatan pembelajaran diantaranya: (1) proses pembelajaran lebih menarik peserta didik supaya bisa menumbuhkan motivasi dalam belajar bagi peserta didik; (2) bahan yang jelas dalam pengajaran akan lebih bermakna, sehingga akan memudahkan peserta didik, selain itu akan memungkinkan peserta didik dalam mencapai tujuan pembelajaran dengan baik; (3) metode pembelajaran yang beragam tidak hanya hanya komunikasi secara verbal tetapi juga melalui penuturan kata-kata lisan dari guru, peserta didik tidak akan bosan, dan guru tidak akan kehabisan tenaga dan pikiran; dan (4) peserta didik akan banyak melakukan kegiatan belajar, karena tidak hanya sebagai pendengar penjelasan dari guru saja, melainkan kegiatan lain diantaranya mengamati, melakukan, dan mendemonstrasikan serta lainnya.

Pemanfaatan media yang sesuai oleh guru dalam pembelajaran khususnya pembelajaran biologi akan sangat membantu baik guru maupun peserta didik. Sehingga guru dituntut mampu menggunakan suatu media yang sesuai dengan pembelajaran yang dilakukan. Media powerpoint interaktif merupakan slide interaktif yang berisi materi pembelajaran sehingga bisa dimanfaatakan sebagai media dalam pembelajaran biologi. Powerpoint suatu program berbasis multimedia yang dilengkapi dengan fitur-fitur menarik yang dirancang secara khusus sebagai alat presentasi yang memiliki kemampuan pengolahan teks, warna, gambar, dan animasi yang bisa diolah sendiri sesuai dengan kreativitas dari penggunanya. Berdasarkan hasil penelitian Damayanti \& Qohar (2019) powerpoint interaktif praktis dalam penggunaannya sehingga bisa membantu peserta didik memahami materi yang disampaikan. Tujuan dari penggunaan media dalam proses pembelajaran biologi supaya peserta didik bisa berinteraksi dengan lebih baik dan adanya penerapan teori yang telah didapatkan peserta didik.

Pada proses pembelajaran biologi, pemanfaatan salah satu media yaitu media powerpoint interaktif (Gambar 1) dilakukan dengan cara memberikan file powerpoint interaktif yang berisikan materi biologi pada setiap peserta didik sehingga masingmasing peserta didik dapat mengoperasikan media tersebut pada handphone. Peserta didik dapat lebih aktif, belajar secara mandiri, materi biologi yang disajikan jauh lebih menarik, dan lebih mudah dalam mempelajarinya. Selain itu, juga sangat bermanfaat untuk membantu meningkatkan aktivitas dan hasil belajar peserta didik pada pelajaran biologi (Gambar 2). Sejalan dengan hasil penelitian Umam (2013) menandakan aktivitas dan 
hasil belajar peserta didik yang mengikuti proses pembelajaran dengan media lebih baik dan temasuk dalam kritera sangat baik dibandingkan dengan aktivitas dan hasil belajar peserta didik tanpa menggunakan media.

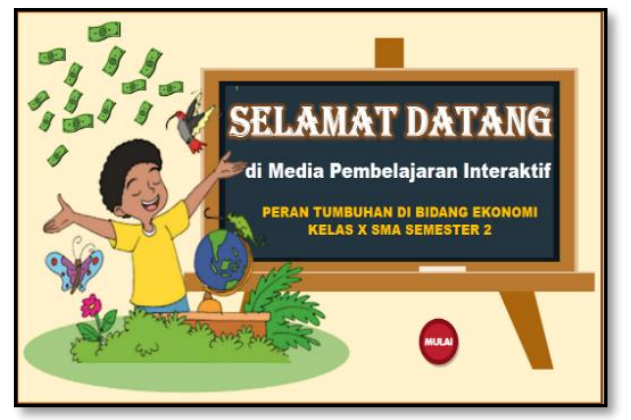

Gambar 1. Contoh tampilan powerpoint interaktif

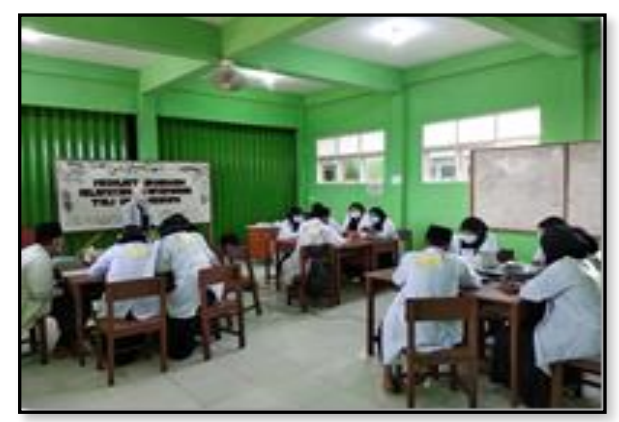

Gambar 2. Pemanfaatan powerpoint interaktif dalam pembelajaran biologi

Media pembelajaran memiliki peran penting pada kegiatan pembelajaran biologi, karena melalui media guru bisa memberikan materi yang lebih menarik kepada peserta didik sehingga pembelajaran biologi menjadi lebih bermakna (Wahyuningtyas \& Sulasmono, 2020). Guru tidak hanya sekedar menyalurkan materi berupa ceramah namun bisa mengarahkan peserta didik untuk memahami secara konkret tentang materi biologi yang diberikan tersebut. Terkait hal di atas, media pembelajaran powerpoint interaktif dapat dijadikan sebagai sebagai penghubung antara guru dan peserta didik dalam proses pembelajaran bilogi. Peserta didik akan lebih mudah dalam memahami materi pembelajaran biologi sehingga proses pembelajaran yang berlangsung menjadi lebih efektif.

Media sebagai penghantar pesan dari guru kepada peserta didik. Berdasarkan yang telah dipaparkan, media pembelajaran merupakan perantara yang digunakan untuk menyampaikan pesan atau informasi dari tenaga pendidik kepada peserta didik dalam proses pembelajaran biologi sehingga pesan (makna) atau informasi yang disampaikan guru lebih mudah untuk dimengerti peserta didik. Media pembelajaran powerpoint interaktif yang dimanfaatkan sebagai media untuk menyampakan materi biologi dapat berperan sebagai basis belajar bagi peserta didik untuk memperoleh informasi yang disalurkan oleh guru supaya materi pembelajaran biologi bisa lebih meningkat dan membentuk pengetahuan bagi peserta didik (Aghni, 2018).

Pemanfaatan powerpoint interaktif sebagai media pembelajaran biologi di SMA bisa menambah motivasi. Selain itu, juga meningkatkan hasil belajar peserta didik, dikarenakan powerpoint interaktif direspons dengan sangat baik oleh peserta didik baik kognitif, afektif, dan psikomotorik (Wulandari, 2019). Media powerpoint interaktif dapat dimanfaatkan dalam pembelajaran biologi. Hal ini karena dapat memudahkan peserta didik dalam memahami materi pelajaran, penggunaannya praktis, informasi yang disajikan lebih jelas, penyajian yang lebih menarik yang bisa memunculkan motivasi belajar peserta didik dan tidak menimbulkan kebosanan dalam menempuh proses pembelajaran di kelas.

Hal di atas, sejalan dengan penelitian yang dilakukan oleh Krissantono (2013) mengenai pemanfaatan media pembelajaran meningkatkan motivasi belajar peserta didik ilmu pengetahuan alam yang ditunjukkan dengan adanya perubahan terhadap motivasi belajar siswa didapatkan hasil peningkatan motivasi intrinsik yang muncul yaitu dengan rata-rata $81.47 \%$, dengan jenjang kenaikan sangat tinggi. Sedangkan motivasi ekstrinsik yang tidak muncul dengan rata-rata $18.51 \%$, dengan jenjang kenaikan sangat rendah. Sementara pada hasil peningkatan motivasi ekstrinsik yang muncul yaitu dengan rata-rata $87.82 \%$, dengan jenjang kenaikkan sangat tinggi. Sedangkan motivasi ekstrinsik yang tidak muncul dengan rata-rata $12.16 \%$, dengan jenjang kenaikkan sangat rendah. Ini menunjukkan bahwa penggunaan suatu media dalam pembelajaran bisa dimanfaatkan dengan maksud untuk meningkatkan motivasi belajar peserta didik.

\section{KESIMPULAN}

Pemanfaatan powerpoint interaktif sebagai media pembelajaran biologi di SMA, media pembelajaran bagi guru, yaitu sebagai rekomendasi pedoman bagi guru guna mencapai tujuan dalam 
pembelajaran supaya bisa mengemukakan materi pembelajaran dengan urut dan menolong dalam penyampaian materi supaya lebih menarik sehingga bisa meningkatkan mutu dalam pembelajaran. Selain itu pemanfaatan powerpoint interaktif sebagai media pembelajaran biologi di SMA, bagi peserta didik, yaitu bisa menambah motivasi dan juga hasil belajar peserta didik supaya bisa berpikir dan menganalisis suatu materi yang sudah disampaikan oleh guru dengan situasi belajar yang menarik serta peserta didik dapat paham terhadap materi dengan lebih mudah.

\section{UCAPAN TERIMA KASIH}

Terima kasih kepada pembimbing, tim payung penelitian dengan dana mandiri, dan Community Development \& Outreaching Universitas Tanjungpura Pontianak serta Ditjen Belmawa Kemenristekdikti yang telah memberikan beasiswa bidikmisi, dan Winda Tri Utami yang sudah membuat media.

\section{DAFTAR PUSTAKA}

Alwi, S. (2017). Problematika guru dalam pengembangan media pembelajaran. ITQAN: Jurnal Ilmu-ilmu Kependidikan, 8(2), 145-167.

Aghni, R. I. (2018). Fungsi dan jenis media pembelajaran dalam pembelajaran akutansi. Jurnal Pendidikan Akutansi Indonesia, 16(1), 98-107.

https://doi.org.10.2183/jpao.v16i1.20173.

Alfan, A., \& Sulistiyo. (2015). Perbandingan media pembelajaran (Auto Play Media Studio) sebagai alat bantu pembelajaran memperbaiki CD player siswa kelas XI di SMK Negeri 3 Surabaya. Jurnal Pendidikan Teknik Elektro, 4(1), 39-47.

Damayanti, P. A., \& Qohar, A. (2019). Pengembangan media pembelajaran matematika interaktif berbasis powerpoint pada materi kerucut. Jurnal Matematika KreatifInovatif, $\quad 10(2), \quad 119-124$. https://doi.org/10.15294/kreano.v10i2.16814.

Jayawardana, H. B. A. (2017). Paradigma pembelajaran biologi di era digital. Jurnal Bioedukatika, 5(1), 12-17. http://dx.doi.org/10.26555/bioedukatika.v5i1.5 628.

Krissantono. W (2013). Pemanfaatan media pembelajaran meningkatkan motivasi belajar siswa Ilmu Pengetahuan Alam kelas VI SDN 03
Kelampai. Jurnal Pendidikan dan Pembelajaran Khatulistwa, 2(8), 1-18.

Maskur, R., Nofrizal., \& Syazali, M. (2017). Pengembangan media pembelajaran matematika dengan Macromedia Flash. AlJabar: Jurnal Pendidikan Matematika, 8(2), 177-186.

https://doi.org/10.24042/ajpm.v8i2.2014.

Nurhidayati., Asrori, I., Ahsanuddin, M., \& Dariyadi, M. W. (2019). Pembuatan media pembelajaran berbasis powerpoint dan pemanfaatan aplikasi android untuk guru Bahasa Arab. Jurnal Karinov, 2(3), 181-184. http://dx.doi.org/10.17977/um045v2i3p181184.

Nurrita, T. (2018). Pengembangan media pembelajaran untuk meningkatkan hasil belajar siswa. MISYKAT: Jurnal Ilmu-ilmu Al-Quran. Hadist, Syariah, dan Tarbiyah, 3(1), 171-210. https://dx.doi.org/10.33511/misykat.v3n1.171.

Pramuaji, A. (2017). Pengembangan media pembelajaran interaktif pada materi pengenalan Corel Draw sebagai sarana pembelajaran desain grafis di SMK Muhammadiyah 2 Klaten Utara. Electronics, Informatics, and Vocational Education, 2(2), 183-189. https://doi.org/ 10.21831/elinvo.v2i2.17312.

Purworaharjo, S., \& Firmansyah, G. (2018). Tinjauan literatur secara sistematis pada selfservice business intelligence. Konferensi Nasional Sistem Informasi (pp. 986-990). Pangkal Pinang, Indonesia: STMIK Atma Luhur Pangkal Pinang.

Tafonao, T. (2018). Peranan media pembelajaran dalam meningkatkan minat belajar mahasiswa. Jurnal Komunikasi Pendidikan, 2(2), 103-114. https://doi.org/10.32585/jkp.v2i2.113.

Umam, K. (2013). Penerapan media digital dalam pembelajaran apresiasi batik kelas X SMA Negeri 1 Blega. Jurnal Pendidikan Seni Rupa, 1(1), 100-105.

Utami, W. T. (2021). Pengembangan Powerpoint Interaktif pada Submateri Peran Tumbuhan di Bidang Ekonomi Kelas X SMA dengan Produk Olahan Wafer Cookies Ubi Jalar Ungu (Ipomoea batatas L.). Skripsi. Universitas Tanjungpura Pontianak.

Wahyuningtyas, D. T. (2017). Pelatihan media pembelajaran matematika berdasarkan Kurikulum 2013 bagi guru Sekolah Dasar di Gugus 9 Kesamatan Sukun Malang. Jurnal Dedikasi, 14, 8-11. https://doi.org/10.22219/dedikasi.v14i0.4293. 
Wahyuningtyas, R., \& Sulasmono, B. S. (2020). Pentingnya media dalam pembelajaran guna meningkatkan hasil belajar di Sekolah Dasar. Edukatif: Jurnal Ilmu Pendidikan, 2(2), 23-27.

Wulandari, A. (2019). Pengembangan Media Powerpoint Interaktif Pembuatan Biscotti
Nanas (Ananas Comosus L. Merr.) pada Submateri Peran Tumbuhan di Bidang Ekonomi Kelas X SMA. Skripsi. Universitas Tanjungpura Pontianak.

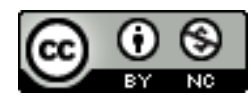

This work is licensed under a Creative Commons Attribution-NonCommercial 4.0

International License 